\title{
EXPORTING CITIZENS, IMPORTING REMITTANCES \\ The Developing World's Newest Strategy to Combat Poverty
}

TODAY, THREE PERCENT OF THE WORLD'S POPULATION LIVES AND WORKS OUTSIDE ITS COUNTRY OF BIRTH. THIS RISE IN MIGRATION HAS LED TO A SURGE IN REMITTANCES, WHICH NOW REPRESENT THE MOST IMPORTANT SOURCE OF INCOME FOR MANY DEVELOPING COUNTRIES. THIS PAPER WILL FOCUS ON THE DEBATE SURROUNDING THE IMPACT OF REMITTANCES ON POVERTY AMONG BOTH RECEIVING HOUSEHOLDS AND THE NON-RECEIVING COMMUNITY IN THE COUNTRY OF ORIGIN, CONCLUDING THAT REMITTANCES HAVE A HIGHER PROPENSITY TO BE INVESTED IN EDUCATION, HEALTH, AND ENTREPRENEURSHIP THAN NON-REMITTANCE BASED INCOME. ITS FINDINGS HIGHLIGHT THE POTENTIAL OF A SUSTAINABLE METHOD OF SOUTH-TO-SOUTH DEVELOPMENT THAT MAY VERY WELL REDEFINE HOW POLICY MAKERS APPROACH MIGRATION AND DEVELOPMENT. 


\section{INTRODUCTION}

The growing demographic and economic dichotomy between the developed and developing world continues to fuel the rise of international migration into the twenty-first century. Today, $3 \%$ of the world's population- $\mathrm{I} 75 \mathrm{mil}$ lion-live and work outside their country of birth, a phenomenon highlighted by a movement of workers from less developed countries to more developed countries. This large migratory flow brings with it heavy social, political, and economic baggage, affecting both the new host country and the country of origin. Early research on international migration has been dominated by a focus on the negative aspects of international migration, highlighting its drain not only on its new host society, but also on the negative consequence of migrants on the economic development of sending countries.

Only recently have governments, scholars, and members of the civil society begun to explore the potential benefits of international migration on the development of the countries of origin, long thought to be the biggest losers of the outflow of human capital. One of the biggest reasons for this changing mindset is the rise of international migrant remittances sent back from their host country to family in their country of origin. As remittances surge and begin to outstrip development aid to the developing world in terms of income flow, policy makers and scholars have engaged in a debate about whether remittances can contribute to development in receiving countries and, if so, which policies should be enacted to maximize inflows and benefits.

This paper will focus on this debate of the impact of remittances on the developing world with a particular investigation on its effect on poverty among both receiving households and the non-receiving community in general. Using numerous studies conducted around the world, this paper will show that remittances do in fact have the potential to reduce poverty. By increasing household income, remittances have a higher propensity to be invested in education, health, and entrepreneurship than non-remittance based income.

\section{INTERNATIONAL WORKER MIGRATION:}

\section{SCOPE AND TRENDS}

International migration is not a new phenomenon. The nineteenth and twentieth centuries witnessed a mass migration of millions of workers to the shores of America and Australia. Recent decades, however, have seen an unprecedented rise in migration. The number of international migrants rose from 76 million in 1960 to 80 million in 1972 and has since more than doubled to over 175 million migrants throughout the world. ${ }^{\mathrm{i}}$ This latest wave of migration has been dominated by a trend of migrants moving from less developed countries to industrialized, developed countries in the Organisation for Economic Co-operation and Development (OECD). While the growth of South to South migration-migration between two developing countries - actually fell over the past decade, migration to industrialized countries has notably been increasing since the I970 S. Each decade from I970 to 2000 witnessed a $2.4 \%$, $2.9 \%$, and $3.1 \%$, growth in migrants destined for industrial countries, respectively.

Migration in North Africa and the Middle East presents a more complicated picture. Both regions are characterized as labor sending and receiving countries with massive outflows of migrants from the Maghreb to Europe and an equally impressive inflow of Asian and Indian migrants to the Gulf States. Further complicating the picture is-at least until recently-a strong trend towards interregional migration from Arab countries to the Gulf (a phenomenon which is increasingly being reduced thanks to the influx of Asian and Indian workers to fill labor intensive, low wage jobs). Jordan, Syria, and especially Egypt sent large number of workers to the Gulf, which, coupled with Asian and Indian workers, represented $40 \%$ of the Gulf's population at its peak in the I990s. ${ }^{\text {iii }}$ In fact, recent statistics have revealed that South to South migration is again on the rise after decades of decline, with the region hosting a growing number of South to South migrants. Nearly $2 \%$ of North Africa and the Middle East's population are migrants, particularly from Asia, India, and Sub-Saharan Africa, a trend which looks to continue in the future as migrants from 
Sub-Sahara continue to flood the Maghreb. ${ }^{\text {ix }}$

Compared to other regions of the world, however, the Middle East and North Africa have lower emigration flows. Lebanon is the only country in the region with an emigration rate over 10\%, and Morocco, long the leader of labor exportation in the region, sends less than $8 \%$ of its labor force abroad. ${ }^{\vee}$ By contrast, nearly half of Latin American and Caribbean countries have over 10\% of their labor force living abroad.

\section{RECENT REMITTANCE TRENDS: SCOPE AND FACTORS}

As the number of international migrants-particularly to industrialized countries - rises, so too does the amount of income sent back to developing countries in the form of remittances. Scholars and governments, who began to change their policies recently in order to develop better ties with their migrants and to encourage more remittances, have come to recognize remittances as a substantial and increasingly important source of income for developing countries.
SCOPE

The sheer size and pace of the growth of remittances place it at the forefront of the migrant led development discussion. In I970, when remittances first emerged as a serious topic of debate and statistical record, international migrant remittances totaled only $\$ 2$ billion. ${ }^{\text {vii }}$ In just a few years time, the later part of the decade saw an average amount of remittances numbering $\$ 7.8$ billion. ${ }^{\text {viii }}$ Remittances doubled in one year from I979 to I980, when they amounted to $\$ 18.4$ billion. Since then, remittance flows have experienced an almost exponential rate of growth. The annual average soared 12 times the amount sent during the midI970s to \$98 billion between I998 and 2003. By 2003, gross flows of remittances to developing countries equaled \$I42 billion. Even the yearly growth is truly staggering. 2004 witnessed a nearly $\$ 20$ billion increase in remittances to $\$ 160$ - a $66 \%$ increase in the gross receipt of migrant remittances of developing countries between 200 I and 2004 . ${ }^{\text {ix }}$ This growth shows no sign of letting up in the future. As statistics continue to pour in, the World Bank estimates that in 2007 , migrant remittances may very well have totaled over \$300 billion-doubling the amount of income flowing into the world's poorest countries in a span

WORKERS REMITTANCES AND OTHER FOREIGN EXCHANGE FLOWS TO DEVELOPING COUNTRIES, 1970-2003.

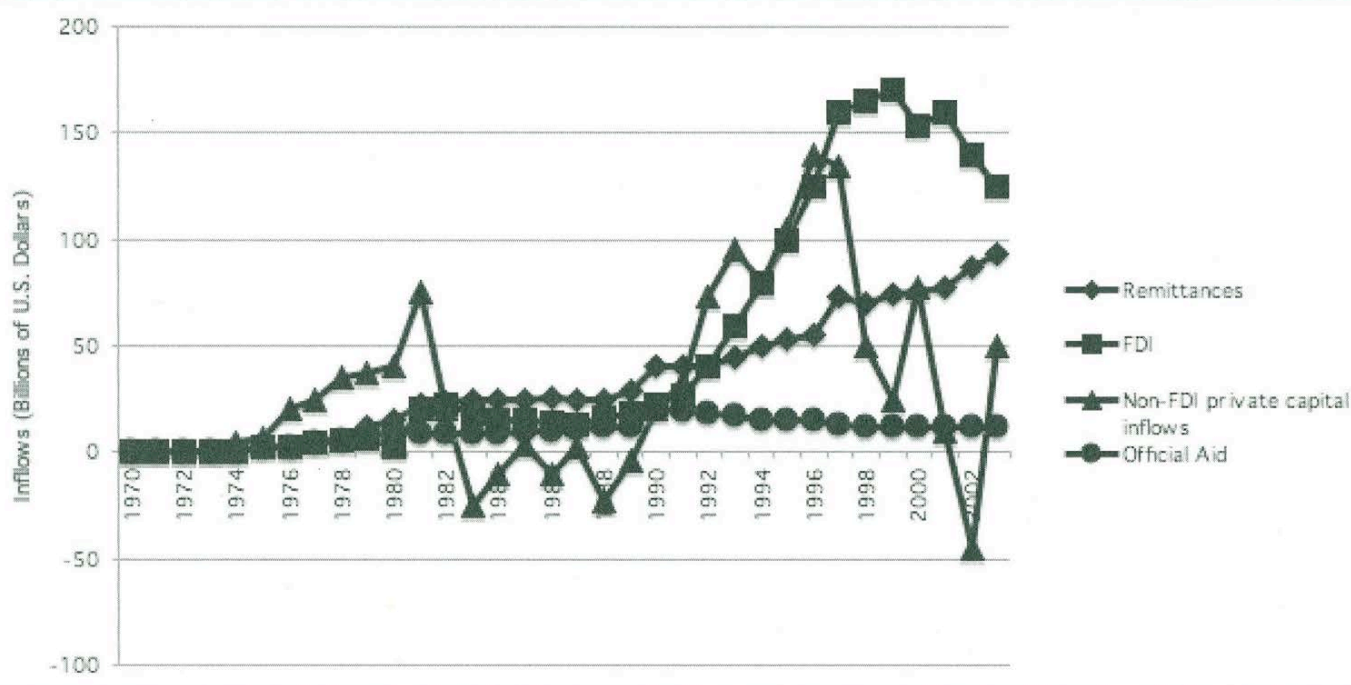


of just four years.

The magnitude of this rise is best understood when examined within the context of other macroeconomic indicators available in developing countries. In North Africa and the Middle East, worker remittances accounted for anywhere between $2 \%$ and $22 \%$ of their Gross Domestic Product (GDP). Egypt, the largest recipient of remittances in the region during the I990s and among the highest net remittance recipients relative to net migration in the world, received an average of US $\$ 3.279$ billion accounting for $5.45 \%$ of its entire GDP throughout the decade. ${ }^{x i}$ Morocco, also among the highest net remittance recipients relative to net migration in the world, experienced a remittance to GDP percentage of $4.24 \%$ during the I990s. ${ }^{x i i}$

These GDP statistics reveal the magnitude and, in effect, the importance of remittances to developing countries. But simply examining the amount of remittances to GDP is not enough. To fully understand the magnitude of remittances to the developing world, one must conduct a cross-analysis of remittance flows with other sources of income for developing countries. Characterized by narrow domestic markets and a scarcity of investment and capital, poor countries depend heavily on outside sources of income, including foreign direct investment (FDI), development aid, and running a budget deficit.

Remittances have been shown to be both more sustainable and stable than more volatile sources of foreign income, including FDI and development aid.xii As the figure above reveals, remittances long ago outstripped development aid and non-FDI private capital inflows to become the second largest source of income for developing countries. Analyzing the flows of the different incomes, the stability of remittances quickly becomes apparent compared to the volatility of FDI. In 2004, remittances accounted for more than $5 \%$ of developing countries' imports and $8 \%$ of domestic investment.xiy
FACTORS

Because individuals migrate for different reasons, scholars have yet to reach a consensus regarding the most important factor determining the amount and motive of specific migrant remittances. Three trends are apparent when analyzing the factors behind migrant remittances: altruism (assisting family and friends in need), insurance (providing family back home with a source of income were there to be

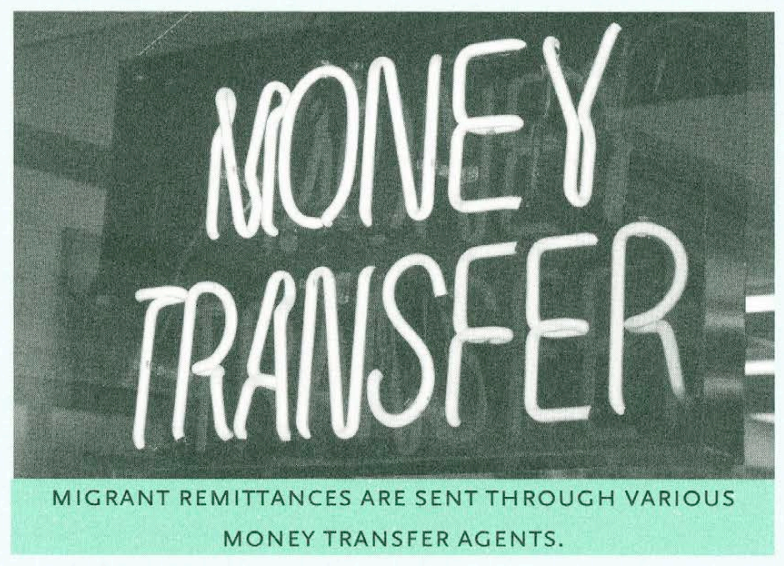

a shock or disaster), and investment (either for family left behind or as a move to accumulate assets for an eventual return of the migrant). Studies have shown that remittance factors vary significantly across countries and migrant situations.

Additionally, migrants utilize a wide variety of tools to facilitate their remittance transfer, including banks, credit unions, financial transfer companies, postage, and hand delivered cash. The factors determining which channel a migrant will use-formal or informal-to transfer his income varies from situation to situation. It has been noted that the main obstacle migrants face when trying to utilize formal channels, and thus more secure and efficient means of transfer, is the sheer absence of banking facilities or similar financial services connecting their host community with their community of origin. ${ }^{\mathrm{xV}}$ In many cases, especially in Africa, the financial network needed to transfer remittances simply does not exist in rural communities. 
However, the mere existence of these financial networks does not guarantee that a migrant will utilize them. High transfer costs are another main obstacle migrants face in utilizing formal channels, reducing both the volume and the effect of these potentially massive flows.

Banks and credit unions usually levy high fees for transferring cash around the world, charging migrants both a fee for the transaction and a commission on the amount of currency converted. Ghosh highlights the astronomical cost for these often low skilled and low income earning migrants: the average cost of sending \$200 from a sample of 6 countries-France, Germany, Saudi Arabia, South Africa, the United Kingdom, and the United States-to I4 receiving countries around the world totaled $6 \%$ if sent through transfer companies, $7 \%$ if sent through banks, and I2\% if sent through international money transfer companies such as Western Union. Examining transfer costs to individual countries, especially among the leading remittance recipients, reveals even higher costs. Moroccan migrants, who send back the fourth highest amount of remittances in the world, face a stiff average transaction cost of I4\%. xvi Much to the detriment of migrants, these high fees do not actually represent the true cost of transfer borne by financial institutions. Rather, these high fees can be blamed on the imperfection of the financial sector, including a lack of competition coupled with a lack of efficiency in developing countries. As a result, almost a fifth (I7\%) of international migrants still use informal channels of remittance transfer, including mail and hand delivery. xvii This study by Ghosh highlights the untapped potential of policy interventions in improving financial markets and thus reducing costs in order to increase the volume of formal remittances.

\section{REMITTANCES AND POVERTY}

Given the increase in remittance flows to developing countries over the past decades, scholars have begun to analyze the effect of remittances on the economic development and growth of receiving countries. A watershed moment in the debate came in 2005, when the World Bank concluded that remittances do in fact have a positive effect on the development and welfare of receiving countries, a claim which has since been supported by numerous studies. The debate has revolved around the nature of remittances, which many characterize as a private transfer of income used not for productive investments, but rather for consumption of basic commodities. Because of the private nature of remittances and the historical failure of governments to capture the income flows for greater development uses, many scholars have argued that remittances are nothing more than a method to increase household consumption in receiving countries, and may in some instances actually harm the receiving country's economy. Led by the World Bank, a growing number of scholars and studies have emerged to support the positive impact of remittances on development and especially poverty, both from the macroeconomic and microeconomic side.

\section{"In communities where a} majority of a households' small income goes towards mere survival, remittances allow these families to appropriate greater income towards human capital, which is in itself the most important investment for the future of these communities." 
REMITTANCES AND THE MICRO-ECONOMY: DIRECT POVERTY REDUCTION

The debate of the microeconomic effects of remittances revolves around the perceived household use of this newly found source of income. A review of relevant literature reveals that there is general agreement that most remittances are used for household consumption purposes, rather than what economists would coin productive investment. xviii Using this as ammunition, some scholars dismiss the development potential of remittances, writing them off as pure consumption-based income. This analysis, however, misses the productive elements of consumption, especially in such poor countries. In these communities, consumption of goods such as education and healthcare represent a type of productive consumption investing in human capital. In fact, numerous studies have shown that "many of the consumption investments financed by remittances make positive contributions toward human development in poor areas," including "spending on nutrition, health, and education." xix In communities where a majority of a household's small income goes towards mere survival, remittances allow these families to appropriate greater income towards human capital, which is in itself the most important investment for the future of these communities.

John Page and Sonia Plaza put forward one of the most comprehensive studies on remittances and poverty reduction, using a data set that includes statistics on migration, remittances, and poverty for 74 developing countries. The report finds that remittances have a strong impact on reducing poverty in recipient countries across the world: "A IO\% increase in the share of international migrants in the population or of remittances received in GDP reduces the fraction of people living on less than one dollar per day by I. $9 \%$ and $1.6 \%$ respectively." $\times x$ In addition to lifting individuals out of poverty, the study found that an increase in remittance also reduces the depth and severity of poverty.

Nikola Spatafora's 2005 study of IOI developing countries throughout 1970-2003 reached many similar conclusions. Measured by use of poverty headcounts and the poverty gap between high and low income individuals, Spatafora argues that there is a clear inverse relationship between the level of remittances and poverty-the more the remittances, the lower the level of absolute poverty. There is clear evidence that remittances reduce poverty in the developing world especially when unofficial remittances are taken into account.xxi Case studies in some of the poorer remittance recipient countries highlight the impact of remittances in even the poorest of communities. A study done in Burkina Faso-ranked second to last on the UN's human development index-reveals that remittances have led to a reduction of poverty by $7 \%$ in rural areas and by $3 \%$ in urban areas.xxii

Contrary to one of the greatest criticisms levied against remittances-that they do not flow to the poorest countries and households - this significantly highlights the potential of remittances to reach even the poorest of the poor. This is further supported by a household survey conducted by Ratha, which suggests that remittances have significantly reduced the poverty headcount in several low-income countries "by II percentage points in Uganda, 6 percentage points in Bangladesh, and 5 in Ghana. In Nepal, remittances may explain a quarter to a half of the II percentagepoint reduction in the poverty headcount rate over the past decade (in the face of a difficult political and economic situation)."xxiii

\section{EDUCATION AND HEALTH}

A main reason for the reduction in poverty, besides the inherent rise in income for impoverished households, is the tendency for remittent receiving households to invest in human capital, especially education and healthcare. In fact, Richard Adams, Jr. reveals, that "households receiving remittances actually spend less at the margin on [basic] consumption - food and consumer goods and durablesthan do households receiving no remittances."xxiv Specifically, Adams finds that a particularly large amount of remittance income is spent on education in receiving countries, especially on the margin, where "households receiving internal and international remittances spend $45 \%$ and 
$58 \%$ more, respectively, on education than do households with no remittances." XXv

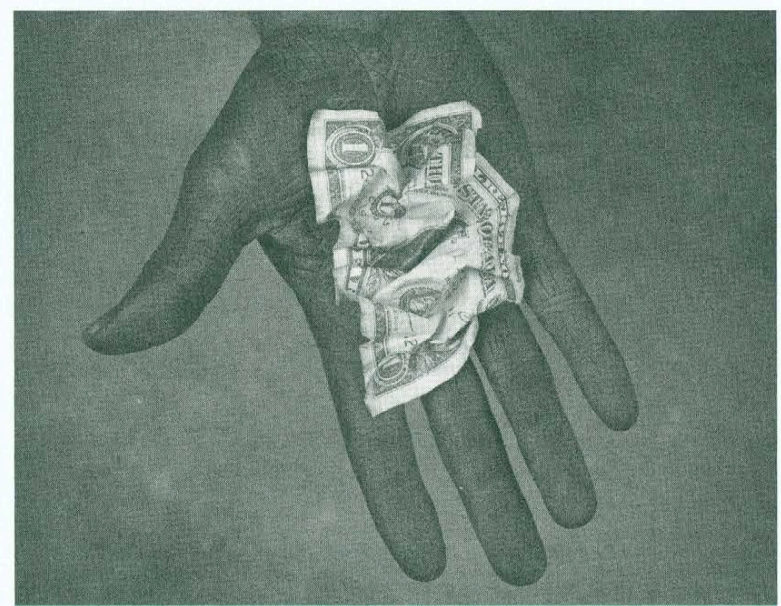

REMITTANCES REDUCE POVERTY IN RECIPIENT COUNTRIES ACROSS THE WORLD.

A number of other studies make the same conclusion about the higher propensity to "consume" education by remittance recipients. A recent study conducted by Dean Yang, which analyzed the impact of remittances in the Philippines, found that "a rise in remittances of I0\% of initial income will increase the fraction of children, aged $I 7$ to 2I, attending school, by more than Io percentage points." xxvi The impact of remittances is especially evident in El Salvador, where roughly $15 \%$ of all households received remittances in I997. Surveying a large sample of I4,286 individuals aged 6-24, the study made the fairly representative conclusion that remittance income in El Salvador has a much larger impact on school retention than any other source of income, including official aid.xxvii Providing households with the additional income needed to allow their children to attend school-poor households often rely on child labor for supplementary income or simply cannot afford the costs of education-it was found that "in urban areas the average level of remittances lowers the hazard that a child will drop out of elementary school by $54 \%$ " and that "the average level of remittances in rural areas lowers the hazard rate that a child will drop out of elementary school by $14 \%$." xxviii

Healthcare also received considerable attention from remittance recipients and their higher incomes. The Mexican Migration Project, which studies migration flows from the United States and Mexico, found that three quarters of migrants in the United States who remit a portion of their income spent a portion of their funds on healthcare. xxix This is backed up by research done by Frank and Hummer in 2002, whose study argues that children born into remittance receiving families are healthier at birth and exposed to less health risk than non-remittance receiving households. Lopez Cordova provides some impressive statistics to sustain these claims, concluding that "if the fraction of remittance-receiving households increased by five percentage points, starting from zero, infant mortality falls by almost 5\%, children's school attendance rises by more than $3 \%$, and illiteracy drops by $34 \%$." ${ }^{x x x}$

The increased income as a result of remittances not only improves health access, but also health knowledge, an essential tool in especially poor and rural areas where healthcare may be limited. A study presented by Plaza and Sonia found that mothers in migrant households have more health knowledge than their counterparts in non-migrant households, importantly, they also find significantly higher levels of health knowledge among non-migrant households in high migration communities, supporting the hypothesis that knowledge spillovers exist within these communities. ${ }^{\mathrm{xxxi}}$

\section{NVESTMENTS}

As the effects of remittances on health and education become established, many skeptics still point out that remittances are rarely, if ever, used on productive investment such as starting a business, and therefore are out of the policy scope of development goals. Early studies did make strong arguments that remittance income was used mainly for consumption. In his review of international remittance trends, Dovelyn Rannveig Agunias points out that in Latin 
America, more than $80 \%$ of remittance receiving households reported using their new income to cover basic necessities. xxxii

There is, however, a growing body of evidence to suggest that productive investments vis-à-vis remittances, especially in low-income countries, are actually on the rise. Adams finds that in Guatemala - a country ranked II 8th on the UN's Human Development Index-a majority of remittance income was not spent on basic goods. The study found that "at the mean level of expenditures, households without remittances spend $58.9 \%$ of their expenditure on consumption goods compared to $55.9 \%$ on the part of households receiving international remittances."xxxiii Adams suggests, along with a growing number of migrant scholars, that households have a higher propensity to invest their remittances than ordinary income because remittances are seen as temporary income. The temporary nature of the income prevents frivolous consumption as

"This bottom-up process allows income to flow exactly where it is needed without flowing through the inefficient channels of governments or foreign investors who lack the in-depth knowledge which migrants possess about their

own country." households seek to extend the impact of what they see as a short term inflow of cash.

A small but growing number of studies have concluded that remittances are increasingly being spent on entrepreneurial investments. For example, it has been found that a fifth of the capital invested by Mexico's microenterprises was directly funded by remittances from the United States, a number which "reaches $40 \%$ in states with a high number of immigrants to the United States." xxxiv A similar trend is emerging in the Caribbean, where remittances are having a positive impact on private investment. In a study done across 13 countries in the region, a $1 \%$ increase in remittances is linked to a $0.6 \%$ increase in private investment. ${ }^{x x v}$ Egypt, characterized by a large population of temporary emigrants who intend to return to their communities, has also witnessed a rise in investment from remittances, particularly in housing.xxxvi The longer Egyptians spend abroad learning skills and the more income they earn, the more likely they are to become entrepreneurs upon return.xxxvii As Aquanis points out, remittances have been fueling a bourgeoning class of migrant led entrepreneurship:

These recent findings complement earlier studies suggesting that remittances have been critical to the capitalization of migrant-owned businesses. As early as 1990, Escobar and Martinez suggest that $31 \%$ of migrants surveyed in Guadalajara used U.S. savings to set up businesses. Cornelius's study located in three rural Mexican communities suggests an even higher percentage of businesses founded through remittances.xxxviii

\section{REMITTANCE CRITICISMS}

Despite these encouraging results, a number of reservations remain about the impact of remittances on poverty reduction and development on the whole. In addition to criticisms that remittances lead to Dutch Disease and inflation, some scholars worry about the moral hazards to receiving governments as a result of this new windfall in- 
come. xxix By exporting their labor and reaping the benefits of their income that is sent back, governments can ignore the root of the economic problem which sent their migrants off in the first place. At the macro level, government policy "ignores economic imbalances (e.g. trade deficits) and fails to pursue needed economic reforms as it anticipates getting a big slice of dollar remittances every year from migrant workers." It might even "pursue politically beneficial but economically unwise policies" as long as remittances insulate the economy from the negative impact of these policies." $x \mathrm{x}$

Given that many of the receiving countries are characterized by either poor, corrupt, or authoritarian governments (or a combination of all three), this is an especially salient observation. Despite the probability of this theory, there can be no direct linkage between remittances and moral hazard at the state level, especially links that would override the microeconomic benefits of remittances. And while it is out of the scope of this paper to examine the role of the Diaspora on governance and reform, a growing academic consensus on its potential, especially in the case of India, has recognized its benefit and potential to negate this moral hazard and induce governmental reform.

Other skeptics point out that remittances actually work to exacerbate inequality in receiving states. This argument rests on the statistics which reveal that it is not the poorest who migrate. Rather, because of the high costs of migration, it is the upper-lower classes and above which mainly benefit from migration and remittances-especially given the direct and private method of income transfer. This theory is highlighted by studies conducted in both rural Egypt and Pakistan, where data indicates that remittances have led to a sharp income inequality between migrant and nonmigrant families. In Egypt, households in the second and third poorest quintile send the least amount of migrants abroad and are severely underrepresented in remittances. According to Adams Jr.,

It is these variations in the number of migrants produced by different income groups-and not differences in either migrant earnings abroad or marginal propensities to remitthat cause international remittances to have a negative effect on rural income distribution. $\mathrm{xli}$

A number of studies and theories have emerged to question Adam's criticism. In fact, a study of remittances in rural Mexico has concluded the opposite, suggesting that remittances actually marginally reduce income inequality. xlii Rather than exacerbating inequality, a number of other studies conducted in Latin America have concluded that remittances either have a marginal role or a neutral role in reducing poverty. ${ }^{x l i i i}$ It has also been found that while inequality may worsen in the short run, "in the long run the income distribution [of remittances] becomes more equal through the liquidity provided for capital accumulation" and the multiplier effect. xliv

Especially apparent in demand-deficient economieswhere incomes are too low to fuel domestic markets- the massive flow of remittances can induce higher incomes for non-migrant families through the consumption and investment multipliers of remittance receivers. Robert E.B. Lucas notes that "as migrants' families increase their consumption of services or goods produced in sectors with excess capacity, the additional demand can create jobs for other families who in turn spend and create further demands." xly An overarching effect on equality has yet to be found, and its effect varies from country to country depending on the nature of a given country's migration.

\section{CONCLUDING REMARIS}

As official development aid continues to decline and developing countries continue to grapple with development issues, migrant led development is increasingly being regarded as a potential engine of poverty reduction and economic growth. In fact, with migrant remittances to developing countries estimated to be over $\$ 300$ billion annually-and billions more that go unaccounted for-remittances have the potential to turn what was once regarded as the developing world's greatest Achilles' heel-the loss of 
its skilled human capital-into a potential source of development for these desperate countries. Remittances are especially appealing given their source-as remittances outstrip development aid from richer countries, the poor are beginning to support the poor more than the developed world is. This bottom-up process allows income to flow exactly where it is needed without flowing through the inefficient channels of governments or foreign investors who lack the in-depth knowledge which migrants possess about their own country. This self-led development will lead to more sustainable and beneficial long term development.

Remittances are more than a simple private transfer of income spent on immediate consumption. Rather, studies have shown that remittances have a direct impact on reducing poverty by allowing households to invest in human capital, including education and healthcare. The benefits are also apparent in the macro-economy, where, despite the ongoing debate, remittances provide capital strapped countries with the ability to finance development projects.

The recorded ability of remittances to reduce poverty through development is only the tip of the iceberg, however. Through appropriate policy measures of providing a banking infrastructure and incentives to migrant remitters, remittance flows can be expanded and their effect on poverty enhanced. By bringing Multilateral Financial Institutions (MFIs) into the fold, remittances would flow to poorer and more rural households, while at the same time providing the capital to lend to and develop the very same economies. MFIs, with lower cost, are able to open branches in areas where traditional banks cannot, extending the reach of remittances outside of urban communities. Leveraging remittances for development through financial institutions, especially MFIs, would lead to higher income and development for entire receiving communities and states, not just direct remittance recipients. This would, in turn, lead to less reliance on migration and remittance in the first place. Thus, the goal should not only be to cultivate a greater flow of remittances but, rather, to focus on providing the income and infrastructure for developing countries to reduce their reliance on migration and become self-sufficient and developed.

\section{ENDNOTES}

i. Page (3)

ii. Ibid.

iii. Kapiszewski (3)

iv. Page (54)

v. Adams 2006 (3)

vi. Ibid.

vii. de Haas $(605)$

viii. Ghosh (7)

ix. Tbid.

$\mathrm{x}$. Newland

xi. Hatton (335)

xii. Ibid.

xiii. Lucas (156)

xiv. Page (9)

xv. Page, Ghosh

xvi. Ghosh (10)

xvii. Aqunias

xviii. Eversole

xix. Eversole (306)

xx. Page (I9)

xxi. Munzele 2005

xxii. Lucas "Migration and Economic Development" (369)

xxiii. Ratha, Leveraging Remittances (5)

xxiv. Adams 2005

xxv. Ibid.

xxvi. Page (20)

xxvii. Adams 2006.(6)

xxviii. Ibid.

xxix. Eversole (306)

$\mathrm{xxx}$. Page (20)

xxxi. Ibid.

xxxii. Aqunias (25)

xxxiii. Ibid.

xxxiv. Aqunias (26)

xxxv. Ibid.

xxxvi. Ibid.

xxxvii. Adams 2006 (6)

xxxviii. Aqunias (25)

xxxix. Dutch Disease occurs when a country experiences a rise in revenue from natural resources, or in this case remittances, which raises the exchange rate of that country and subsequently harms the country's export sector.

xl. Aldaba

xli. Aldaba (35)

xlii. Lucas 2005 (I89)

xliii. Ibid.

xliv. Lucas (I9O)

xlv. Lucas (156) 


\section{REFERENCES}

Adams, Richard H., Jr. I99I. The Effects of International Remittances on Poverty, Inequality, and Development in Rural Egypt. Research Report No. 86. Washington, DC: International Food Policy Research Institute.

Adams, Jr., Richard H. 2005. "Remittances, Household Expenditure and Investment in Guatemala," World Bank Policy Research Working Paper No. 3532, March 2005.

Adams, Richard H., Jr. 2006. "Migration, Remittances and Development: The Critical Nexus in the Middle East and North Africa." UN/POP/EGM/2006/0I.

Adelman, Irma, and J. Edward Taylor. I990. "Is Structural Adjustment with a Human Face Possible? The Case of Mexico." Journal of Development Studies, 26.3, pp. 387-407.

Aldaba, Fernando. 2004. The Economics and Politics of Overseas Migration in the Philippines. Paper presented at the Overseas Filipinos and the 2004 Elections Forum, Economic Resource Center for Overseas Filipinos. <http://www.ercof.org/papers/ migrationaldaba.html>

Amuedo-Dorantes, Catalina and Susan Pozo. 2004. "Workers? Remittances and the Real Exchange Rate: A Paradox of Gifts," World Development 32.8, pp.1407-1417.

Aqunias, Dovelyn. 2006. "Remittances and Development: Trends, Impacts, and Policy Options," Migration Policy Institute.

Chami, Ralph, Connel Fullenkamp, and Samir Jahjah. 2005. "Are Immigrant Remittance Flows a Source of Capital for Development." IMF Staff Papers, 52.I.

de Haas, Hein and Roald Plug. 2006. "Cherishing the Goose with the Golden Eggs: Trends in Migrant Remittanes from Europe to Morocco 1970-2004," International Migration Review, 40.3 .

Durand, Jorge, Emilio A. Parrado, and Douglas S. Massey. I996. "Migradollars and Development: A Reconsideration of the Mexican Case." International Migration Review, 30.2, pp. $423-44$.

Eversole, Robyn. 2005. "Direct to the Poor Revisited." Migration and Economy. Lillian Trager (Ed.). Rowman Altamira.

Frank, Reanne and Robert A. Hummer. 2002. "The Other Side of the Paradox: the Risk of Low Birth Weight Among Infants of Migrant Households Within Mexico." International Migration Review, 36.3, pp. 746-765.
Ghosh, Bimal. 2006. Migrant's Remittances and Development: Myths, Rhetoric, and Realities, International Organization for Migration. Geneva: Switzerland.

Hatton, Timothy J. and Jeffrey Williamson. 2005. Global Migration and the World Economy. Cambridge, MA: MIT Press.

Kapiszewski, Andrzej. 2006. Arab Versus Asian Migrant. UN/POP/EGM/2006/2.

Lopez Cordova, Ernesto, 2004. "Globalization, Migration and Development: The Role of Mexican Migrant Remittances."

Lucas, Robert. 2005. "International Migration Regimes and Economic Development." Edward Elgar Publishing: Stocholm.

Lucas, Robert. "Migration and Economic Development in Africa: A Review of Evidence." Journal of African Economies, I5, AERC Supplement 2.

Maimbo, Samuel Munzele. 2005. Migrant Labor Remittances In the South Asia Region. Report No 3I 577/ Finance and Private Sector Development Unit. South Asia Region. The World Bank.

Newland, Kathleen. "A New Surge of Interest in Migration and Development," Migration Policy Institute. <http://www.migrationinformation.org/Feature/display.cfm? $\mathrm{id}=580>$. Accessed 29 April 2008.

Page, John and Sonia Plaza. 2005. "Migration Remittances and Development: A review of global evidence." The World Bank, 18 August 2005.

Quartey, Peter., and T. Blankson. 2004. Do Migrant Remittances Minimize the Impact of Macro-volatility on the Poor in Ghana? Final Report Submitted to the Global Development Network (GDN).

Spatafora, Nikola. 2005. "Two Current Issues Facing Developing Countries." In World Economic Outlook: a survey by the staff of the International Monetary Fund.

Yang, Dean. 2004. International Migration, Human Capital, and Entrepreneurship: Evidence from Philippine Migrants' Exchange Rate Shocks. Ford School of Public Policy Working Paper Series, no. O2-orr. University of Michigan, Ann Arbor. 